\title{
Classical Chinese pronouns: Pragmatic implications and politeness
}

\author{
Cher Leng Lee \\ National University of Singapore \\ chsleecl@nus.edu.sg
}

\begin{abstract}
Contemporary Chinese has only one form of first-person pronoun; by contrast, there are at least four different first-person pronominal forms used in Classical Chinese. This makes Classical Chinese first-person pronouns noteworthy to investigate. This co-existence of forms with similar meaning of self-referencing raises two issues, namely the reason behind this co-existence and the relationships among these pronominal forms in terms of sociopragmatic use. Unlike what has been previously argued in the field that address forms rather than pronouns are politeness-related (e.g., Kádár 2007; Pan \& Kádár 2011), first-person pronominal forms in Classical Chinese express a diverse set of contextuallysituated politeness-related meanings. Furthermore, these pronominal forms are socially indexical, in the sense that they are allocated to speakers depending on their social status. Thus, a central argument of this paper is that the pronominal forms studied reveal information about both the person who uses them and the context in which they are used. The paper compares pronominal forms used in the Lunyu 論語 or The analects of Confucius (475 BC-221 BC) and Shishuo Xinyu 世說新語 (A new account of the tales of the world) (200 AD-400 AD), to understand the pragmatic implications and politeness values of these different first-person pronominal forms over a time-span of 400-600 years and also to provide a glimpse of how eventually only one form came to exist in contemporary Chinese.
\end{abstract}

Keywords: politeness; first-person pronouns; Classical Chinese; pragmatic implications; indexicality

\section{Introduction}

The study of pronouns in the field of pragmatics has largely taken place in the domain of politeness (Brown \& Levinson 1987; Kádár \& Haugh 2013). While early research on this phenomenon assumed that there is a direct relationship between politeness and pronominal forms, recently this relationship has been questioned to the extent that a new theoretical question has been raised as to whether pronominal forms can be described in terms of politeness theories at all (e.g., Agha 2007; Helmbrecht 2005; Kádár \& Pan 2012 and Pizziconi \& Watts 2013).

So far, research on this phenomenon has predominantly focused on $\mathrm{T} / \mathrm{V}$ pronouns in European languages (see e.g., Brown \& Gilman 1960; 
Braun 1988; Head 1978; 1981; and Taavitsainen \& Jucker 2003, just to mention a few representative works). This paper argues that like the second-person pronouns in European languages, first-person pronouns in Classical Chinese contain pragmatic implications and politeness-related meanings. Such a finding suggests that we cannot analyze pronominal politeness implications based on European languages alone but must consider pronouns of other languages as well.

Traditionally, Chinese address terms are studied in relation to politeness theories (Kádár 2007). By contrast, first-person pronouns in Chinese are generally treated as neutral pronouns indexing the speaker. This paper demonstrates that first-person pronouns in Classical Chinese have to be approached through the lens of politeness, on the assumption that they are not merely neutral terms referring to the speakers or addressees involved but rather index complex contextual information.

It has been observed that Classical Chinese consists of several firstperson pronominal forms. This has led us to question why there are so many different forms, whether they are different in their sociopragmatic functions, and whether they are related to politeness. To answer these questions, this study has chosen two Classical Chinese texts the Lunyu 論語 or The analects of Confucius (475 BC-221 BC); and Shishuo Xinyu 世說新語 (or $A$ new account of the tales of the world) (200 AD-400 AD), which are 400-600 years apart to examine the numerous first-person pronouns in these texts.

The objectives of this paper are threefold: firstly, to examine in detail the pragmatic implications and politeness values of these first-person pronouns; secondly, to compare how they are used in the two different periods to understand their development; and finally, to discover how they demonstrate the beginnings of a process of convergence which eventually resulted in the use of a sole first-person pronoun in contemporary Chinese. There are at least four different person pronouns in each of these texts. On the surface, they seem to be merely fulfilling the function of indexing the speaker. However, upon closer examination, we will discover that each of them has a particular pragmatic function and is politeness-related. In what follows, I will discuss each of these first-person pronouns in both texts to show how they index pragmatic implications and are driven by politeness considerations.

The theoretical significance of these findings is emancipatory. The study of first-person pronouns in Classical Chinese reveals that one needs to critically challenge the assumption that first-person pronouns are relatively uninteresting for politeness theory, an assumption which stems 
mostly from the academic dominance of European languages in pragmatic research.

The next section provides a background of previous research in this area; section 3 explains the rationale for choosing the two particular texts used in this study; section 4 examines in detail the pragmatic implications and politeness value of each first-person pronoun in the two texts, comparing them side by side; section 5 shows how there remains only one first-person pronoun form in contemporary Chinese; and section 6 concludes the paper.

\section{Synopsis of previous research}

So far, research on Chinese first-person pronominal forms has been carried out in the frameworks of philology (e.g., Elvin 1985; Tu 1994; Wu 1999; Lo 2001; Huang 2003 and Liu 2005), and mainstream linguistics examining the grammatical positions of pronominal forms (e.g., Huang 1963; He 1984; Lü 1985; Wang 2004; Zeng 2005; Zhuang 1984). In Chinese sociopragmatics, address terms rather than pronouns have been the main focal point of inquiry (He \& Ren 2016; Kádár 2007; Liang 2002; Pan \& Kádár 2011). This is because address terms are more transparent in showing politeness values compared to pronouns. It is only in recent years that pragmatics has been used to study these pronouns, revealing many more interesting insights.

A small number of researchers have studied Chinese pronominal forms. Hong (1985) examines how second-person pronouns indicate closer or more intimate relationships, and $\mathrm{Gu}$ (1990) inquires into the sociopragmatic implications of the pronoun nin 您. For first-person pronouns, Mao (1996) studies the social implicatures of the plural pronoun wo-men 我们 'we', and Lai and Frajzyngier (2009) explore the change of functions of these pronouns in Chinese, while Lee $(2012 ; 2016)$ argues that Classical Chinese first-person pronouns are potentially interesting to politeness theory. Zhan (2012) discusses shifts in personal pronouns according to the subjects' footing in political dialogues.

A more thorough and detailed study is needed to demonstrate fully how the numerous first-person pronouns in Classical Chinese are not used at random but rather are loaded with pragmatic implications and politeness-related significance. The present paper fills a knowledge gap by seeking a sociopragmatic answer to the question of why there are various similar pronominal forms in parallel use in these texts. The relationship between these forms and politeness is particularly intriguing because it 
has been accepted that first-person pronouns are not merely self-referring honorifics (Peng 2000; Kádár 2007). An examination into how these pronouns are used with pragmatic implications will show pragmatic factors that determine their individual use.

\section{Data}

To demonstrate how the numerous first-person pronouns are used in Classical Chinese, I have chosen two texts that consist of conversations so that we can observe the relationship of the interlocutors and the issues being discussed. These will give us a more complete understanding of how these first-person pronouns are used. The reason for using two different texts is also to compare how the sociopragmatic functions and politeness values of the first-person pronouns changed and developed over time.

The two Classical Chinese texts studied are Lunyu 論語 or the The analects of Confucius (henceforth referred to as the Analects) and Shishuo Xinyu 世說新語 (or A new account of the tales of the world, henceforth referred to as the New Tales). These sources are chosen firstly because they contain a large number of conversations; in these conversations we are able to capture the sociopragmatic variables such as the identity of the speakers and addressees, the topic of discussion, and so on. Such variables are essential to observe and model how the speakers refer to themselves using the various forms of first-person pronouns in particular contexts. Secondly, these two sources were written about 400-600 years apart, allowing us to compare and contrast how the first-person pronouns developed over the centuries. Although these sources are classical texts, their style is colloquial, and topically they reflect a variety of conversations in everyday life, including conversations between teachers and students, parents and children, and rulers and subordinates.

The first text is The analects of Confucius which consists of conversations between the Chinese philosopher and his students, as well as sayings and ideas attributed to him and his contemporaries; the source was written during the Warring States period (475 BC-221 BC). The English translation chosen for this analysis was done by Lau (2000). The second text is the New Tales which was compiled and edited by Liu Yiqing 劉義慶 (403-444) during the Liu Song dynasty (420-479) of the Southern and Northern Dynasties period (420-589). The New Tales comprises a larger variety of conversations between rulers and their subordinates, between literati, and among family members. The Chinese version used for this study is by Liu 
et al. (2015) which provides explanations of historical details, while the English translation is taken from Mather (2002).

In the Analects, there are 113 occurrences of four first-person pronouns: $w u$ 吾 $(61.7 \%)$, wo 我 (24.6\%), yu 予 (12.6\%) and zhen 朕 (1.1\%). In the New Tales, there are 244 occurrences of five first-person pronouns: wo 我 (68.0\%), wu 吾 $(23.7 \%)$, shen 身 $(4.0 \%), y u$ 予 $(2.8 \%)$ and zhen 朕 $(1.2 \%)$. This surprisingly large number of first-person pronouns is taken for granted by Chinese scholars simply as a variety of pronouns that point to the speaker. For many centuries, neither Chinese linguists nor Western scholars have noticed the hidden messages in these first-person pronouns. In this paper we will discover that through the lens of pragmatics and politeness, we can understand why there are so many of them, and how they are performing different functions that have not previously been recognised. These first-person pronominal forms will be discussed in detail in the next section to give us a better understanding of their respective pragmatic implications and politeness values.

\section{Pragmatic implications and politeness value of the first-person pronouns}

Before examining each pronoun, we need to establish the sociopragmatic variables that determine its contextual use:

1. The social status of the speaker, e.g., an Emperor uses a particular pronominal form as he receives a mandate from Heaven;

2. The social status of the speaker with regards to the addressee, e.g., the speaker will use a particular pronominal form according to whether he has higher or lower status than the addressee;

3. The topic at hand, e.g., a particular form may be used to show respect when the topic concerns death and matters of Heaven;

4. The focus of the speaker, e.g., a form may be used if the speaker aims to contrast himself with others or is simply expressing his own thoughts.

In what follows, we will examine each pronoun to demonstrate how these sociopragmatic variables are used to indicate different contexts and interpersonal relationships in the texts. 


\subsection{Pragmatic implications and politeness value of zhen 朕}

The first-person pronoun zhen 朕 was used as a specialized singular pronoun by Emperors after the first Qin Dynasty (Yuan 1994; Pulleybank 1995; Hong 1996). Chinese Emperors were known as Tianzi 天子 'Son of Heaven'; they occupied the highest social position and it was believed that they received their mandate to rule from Heaven. This pronoun is used similarly by Emperors in both the Analects and the New Tales.

a. In the Analects. Example (1) shows the Emperor using zhen 朕 to refer to himself.

（1） $[\ldots]$ 朕躬有罪，無以萬方; 萬方有罪, 罪在关躬。 $[\ldots]^{1}$ （《論語・堯曰20.1》）

'If I (zhen 朕) transgress, let not the ten thousand states suffer because of me; but if the ten thousand states transgress, the guilt is mine alone. ${ }^{2}$

In the example above, the Emperor refers to his own transgression using zhen 朕 for self-referencing.

b. In the New Tales. Emperor Wen of Wei uses zhen 朕 to refer to himself:

(2) 魏文帝受禪，陳罊有慽容。帝問曰:

‘朕應天受命, 卿何以不樂? ’ 群曰: ‘臣與華歆服膺先朝, 今雖欣聖化, 猶義形於色。

'When Emperor Wen of Wei (Ts'ao P'ei r. 220-226) accepted the abdication of the last Han ruler (Emperor Hsien, r. 190-220), Ch'en Ch'un had a grieved look on his face. The Emperor asked him, 'We (zhen 朕) received the mandate in response to Heaven. Why are you unhappy?' Ch'un replied, 'Your servant and Hua Hsin cherish the former dynasty in our hearts, and today, though we rejoice in your sage rule, still the old loyalty shows in our faces.'(Ch. 5: The Square and the Proper 3) ${ }^{3}$

The Emperor uses zhen 朕 as a self-reference to denote respect to his Heaven-granted position rather than to himself personally, considering that he talks about his own guilt. Ultimately, zhen 朕 is a first-person pronoun that indicates a strong sense of respect and can only be used by the Emperor in reference to his post; the politeness-related meaning of this term is respect directed to Heaven. This is the same in both texts.

${ }^{1}$ All quotations are in the traditional form.

2 The Chinese characters for the pronouns are added.

${ }^{3}$ Mather (2002) uses the Wade-Giles romanization system, when names are mentioned in the text, pinyin romanization will be provided. 


\subsection{Pragmatic implications and politeness value of $y u$ 予/余 (two forms with same function and pronunciation)}

It is recorded that when one prays to Heaven, he usually uses yu 予 rather than wo 我 or $w u$ 吾 (Hong 1996, 84); moreover, according to Chinese philosophers, $y u$ 予 implies a special relationship with Heaven (Lo 2001, 378). Therefore, when one uses $y u$ 予 for self-presentation, he is adopting a position of sacredness in discussing divine and supernatural issues.

a. In the Analects. This pronoun is used when discussing matters of higher order such as death, sickness and spiritual matters. The example below records a speech given by a teacher named Tseng Tzu to his students.

(3) 曾子有疾, 召門弟子曰: ‘啟予足! 啟予手! 《詩》雲 ‘戰戰嗔貺,

如臨深淵, 如履薄冰。' 而今而後, 吾知免夫! 小子! ’ (《論語・泰伯8.3》)

'When he was seriously ill Tseng Tzu summoned his disciples and said, 'Take a look

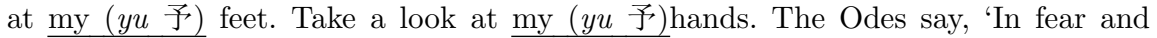
trembling, As if approaching a deep abyss, As if walking on thin ice'. Only now am sure of being spared, my young friends.',4

This excerpt shows that before Tseng Tzu (Zeng Zi 曾子)passes away, he is grateful that he still possesses his hands and legs which are, in effect, given to him by his parents; therefore he refers to them using the $y u$ 予 pronoun. $Y u$ 予 here is the self-referent with respect to his parents who have passed away.

b. In the New Tales. After 400-600 years, yu 予 is still used as a pronoun to show respect in matters concerning death, quoting from the Analects in the New Tales:

（4） 18 傷逝：羊孚年三十一卒，桓玄與羊欣書曰： ‘賢從情所信寄, 暴疾而殞, 祝予之歎，如何可言！'

'When Yang Fu died in his thirty-first year, Huan Hsuan wrote a letter to Fu's cousin, Yang Hsin, in which he said, 'Your worthy cousin was one to whom I could confide my feelings, and now he has died of a sudden illness. The sigh [alluding to a remark by Confucius at the death of Tzu-lu], 'Heaven has cut me (yu 予) off!' - how can I put it into words?' (Chapter 17, Grieving for the Departed 18)'

In this excerpt, before Huan Hsuan (Huan Xuan 桓玄)is about to usurp the Emperor's position, he expresses his sadness over the passing of his confidant in a letter. In the letter, he quotes from the Analects, referring

${ }^{4}$ This means that now on the point of death, he has avoided the risk of the mutilation of his body - a duty which he owed to his parents. 
to himself using $y u$ 予 and lamenting that 'Heaven has cut him off'. He feels that he has lost important people who can help him accomplish his ambition and wonder if it is still Heaven's will for him to carry on with the business of usurping the Emperor. The first-person pronoun $y u$ 予 is used here to express respect for the dead.

In addition, in the New Tales, yu 予 is also used as a pronoun of respect when officialdom is ascribed, as seen in the excerpt below.

(5) 12 規筬: 謝鯤為豫章太守, 從大將軍下至石頭。敦謂鯤曰: “余不得復為盛德之事矣。' [...]

'While Hsieh K'un was serving as grand warden of Yu-chang, he accompanied the generalissimo, Wang Tun, down the Yangtze River as far as Shih-t'ou. Tun said to K'un, 'Never again will I ( yu 余) be able to do such a glorious and virtuous thing!' [...] (Chapter 10, Admonitions and Warnings 12)'

In this excerpt, while Hsieh K'un (Xie Kun 謝鯤) is the grand warden of Yu-chang (Yu-zhang 豫章), Wang Tun (Wang Dun 王敦) is on the verge of starting a rebellion and, seeing that Hsieh K'un (Xie Kun 謝鯤) has the confidence of his contemporaries, Wang Tun (Wang Dun 王敦) compels Hsieh K'un (Xie Kun 謝鯤) to accompany him. Wang Tun (Wang Dun 王敦) tells Hsieh K'un (Xie Kun 謝鯤) that he (Wang Tun or Wang Dun 王敦) will never be able to do such a 'glorious and virtuous thing' in serving the country as a faithful servant. This shows that the pronoun $y u$ 予/余 has extended its use from a pronoun that shows respect to sacred matters and matters of death or sickness to one linked to officialdom. This implies that after 400-600 years, the indexical meaning of the first-person pronoun $y u$ 予/余 has changed.

\subsection{Pragmatic implications and politeness value of $w u$ 吾}

a. In the Analects. The first-person pronoun $w u$ 吾 is used with a sense of humility:

(6) 顏淵死, 顏路請子之車以為之楟。子曰: ‘才不下, 亦各言其子也。鯉也死, 有棺而無楟。吾不徒行以為之楟槨。以吾從大夫之後，不可徒行也。”

(《論語・先進11.8》)

'When Yen Yüan died, Yen Lu asked the Master to give him his carriage to provide for an outer coffin for his son. The Master said, 'Everyone speaks up for his own son whether he is talented or not. When Li died, he had a coffin but no outer coffin, I (wu 吾) did not go on foot in order to provide him with an outer coffin, because it would $\underline{\text { not have been proper for me ( } w u \text { 吾) to go on foot, seeing that I took my place after }}$ the Counsellors.' 
Here Confucius talks about his humble role in the burial of his student compared to that of the Counselors - he uses the humble pronoun wu 吾 to indicate this meaning. The renowned translator Legge (1991, Vol I, 239) emphasized this role of $w u$ 吾 in the style of Confucius; for example, in the translation of the clause ' wu cong da fu zhi hou' 吾從大夫之後 he noted: '[This clause literally means] 'I follow in rear of the great officers'. This is said to be an expression of humility. Confucius, retired from office, might still present himself at court, in the robes of his former dignity, and would still be consulted on emergencies. He would no doubt have a foremost seat at such occasions.'

b. In the New Tales. All 57 occurrences of $w u$ 吾 are used to refer to the self in a humble attitude, as the following example indicates:

（7） 80 賞譽: 殷中軍道王右軍云: ‘逸少清貴人。吾于之甚至, 一時無所後。’

'Yin Hao once characterized Wang Hsi-chih, saying, 'Wang Hsi-chih is a pure and noble man. My ( $w u$ 吾) own relation to him is extremely close. In this fall behind no one else in the entire age.' (Chapter 8 Appreciation and Praise 80)'

This excerpt shows Yin Hao (殷浩), a famous conversationalist, using wu 吾 when he praises Wang Hsi-chih (Wang Xizhi 王羲之), one of China's greatest calligraphers, an aide and administrator) whom he regards as a 'pure and noble man'. This use of the $w u$ 吾 pronoun is consistent with its appearance in the Analects in that it refers to self when talking about personal issues in humility.

\subsection{Pragmatic implications and politeness value of shen 身}

a. In the Analects. This pronoun does not appear in isolation in the Analects: it occurs as a compound with wu 吾 in Analects Book I, Xueer Diyi 學而第一 as wu shen 吾身 which was translated by Lau $(2000,3)$ as 'myself'. This compound form has not been traditionally considered as a first-person pronominal form ' $\mathrm{I}$ ' but rather as a noun meaning 'my + body/self'. Its use is illustrated in the excerpt below:

（8）曾子曰: “吾日三省吾身、為人謀、而不忠乎、與朋友交、而不信 乎、傳不習乎。，(《論語・學而1.4》)

'Tseng Tzu said, 'Every day I ( $w u$ 吾) examine myself ( $w u$ 吾 shen 身) on three counts. In what I have undertaken on another's behalf, have I failed to do my best? In my dealings with my friends have I failed to be trustworthy in what I say? Have I failed to practice repeatedly what has been passed on to me?' 
According to a renowned Chinese grammarian Wang Li 王力 (2000), shen 身 as a pronoun denotes a person carrying out an act personally (zishen 自身, benshen 本身).

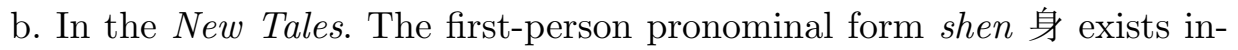
dependently (i.e., not in a compound form) in the New Tales, as seen in the example below:

（9）148賞譽：王子敬語謝公：“公故蕭灑。’ 謝曰: ‘身不蕭灑。君道身最得, 身正自調暢。'

'Wang Hsien-chih said to Hsieh An, 'You're certainly lighthearted and carefree.' Hsieh replied, 'I (shen 身)'m not really lighthearted and carefree, but your characterization is so extremely apt that just naturally, in spite of myself (shen 身), I (shen 身) feel pleasantly cheerful.' (Chapter 8, Appreciation and Praise 148)'

In this excerpt, Wang Hsien-chih (Wang Xianzhi 王獻之, the son of the famous calligrapher Wang Hsi-chih (Wang Xizhi 王羲之) compliments Hsieh An (Xie An 謝安) who is known to be a lighthearted and carefree person. Hsieh replies that as a person he is not really lighthearted and carefree, but Wang's characterization is so apt that despite how he thinks about himself (shen 身), he (shen 身) feels pleasantly cheerful.

Shen 身 used as a pronoun developed from the compound of $w u$ 吾 shen 身 'my+body/self' in the Analects to shen 身 in the New Tales after 400-600 years, treating 'self' as an object.

\subsection{Pragmatic implications and politeness value of wo 我}

a. In the Analects. Wo 我 is used as a first-person pronoun when emphasizing oneself in contrast with others.

（10）司馬牛憂曰: ‘人皆有兄弟, 我獨亡。’ (《論語・顏淵 $12.5 》)$

'Ssu-ma Niu appears worried, saying, 'All men have brothers. I (wo 我) alone have none.',

In the example above, Confucius' student Ssu-ma Niu (Sima Niu 司馬牛) complains that others have brothers while he has none. He is clearly comparing his own desolate state with others who are more fortunate. He uses the pronoun wo 我 to show this contrast between himself and others.

b. In the New Tales. Similarly, wo 我 is also used as a first-person pronoun in relation to other people just as in the Analects, as seen in the example below: 
（11） 35 品藻：桓公少與殷侯齊名，常有競心。桓問殷： ‘卿何如我？，殷云： “我與我周旋久, 寧作我。

'When Huan Wen was young, he and Yin Hao were of equal reputation, and they constantly felt a spirit of mutual rivalry. Huan once asked Yin, 'How do you compare with me (wo 我)?' Yin replied, 'I (wo 我)'ve been keeping company with myself (wo 我) a long time; I (wo 我)'d rather just be me.' (Chapter 9, Grading Excellence 35)'

In this excerpt, Huan Wen (桓温) (who later became a dictator), asks Yin Hao (殷浩) (who was later defeated by Huan Wen (桓温) when he attempted to thwart the latter's ambition) how he compares with Huan Wen (桓温); Yin Hao (殷浩) replies that he would rather be himself. They have been rivals since childhood. Yin Hao's (殷浩)reply shows that he considers himself better than Huan Wen (桓温).

This shows that after 400-600 years, the first-person $w o$ 我 is still used for self-reference emphasizing self in contrast to others. In the next section, we will elaborate on how wo 我 has absorbed the pragmatic functions of the other first-person pronouns. This development shows how eventually wo 我 has become the sole first-person pronoun in contemporary Chinese.

\section{Wo 我 absorbing pragmatic functions of other pronouns}

The first-person pronoun $w o$ 我 is seen to have taken many more pragmatic functions of the other first-person pronouns - zhen 朕, yu 予, and $w u$ 吾 in the New Tales. This development can only be explained by sociopragmatic use, which shows how important and relevant this approach is in shedding new light on the development of pronominal use in particular contexts.

\subsection{Absorbing pragmatic functions of zhen 朕}

We have seen earlier on that in the Analects, the first-person pronoun zhen 朕 is used by the Emperor for self-referencing. However, the data shows that in the New Tales, the Emperor also occasionally uses the first-person pronoun wo 我 for self-reference. We observe that in the New Tales, when the Emperor uses the wo f f first-person pronoun, it is while reprimanding someone. In other words, wo 我 is used by the ruler when displaying displeasure. Such usage is also seen in the following example: 
(12) 11 方正：武帝語和嶠曰: ‘我欲先痛駡王武子, 然後爵之。’ 嶠曰: ‘武子儶爽, 恐不可屈。' 帝遂召武子, 苦責之, 因曰: ‘知愧不? ’武子曰: ‘ ‘布鬥粟” 之謠, 常為陛下恥之! 它人能令疎親, 臣不能使親疎, 以此愧陛下。”

'Emperor Wu said to Ho Ch'iao, 'I (wo 我) wish to give Wang Chi a painful scolding before I confer a noble title on him.' Ch'iao said, 'Wang Chi is bold and forthright; I'm afraid he's not to be intimidated.' The Emperor thereupon summoned Chi and bitterly reprimanded him. Then he said, 'Are you ashamed?' Chi replied, 'The folk song 'A foot of cloth [may still be sewn]; / A peck of millet [may still be hulled]' continually makes me ashamed on behalf of Your Majesty. Others can make the distant intimate, but your servant can't even make the intimate distant. This why I'm ashamed for Your Majesty.' (Chapter 5, The Square and the Proper 11)'

In this excerpt, Emperor Wu (武帝) tells Ho Ch'iao (He Qiao 和嶠), the Emperor's personal assistant, that he wants to reprimand Wang Chi (Wang Ji 王濟), the Emperor's son-in-law, who has earlier been degraded for an offense, before restoring a noble title on him.

This example shows that there is a shift in the use of the first-person pronoun by the Emperor from only zhen 朕 in the Analects to wo 我 in the New Tales when the Emperor is reprimanding someone or showing displeasure.

\subsection{Absorbing pragmatic functions of $y u$ 予}

In the Analects, yu 予 is the first-person pronoun used when referring to matters concerning death to show respect. It is seen in the New Tales that both $y u$ 予 and $w o$ 我 are used in writing an obituary - a subject about death. In the example below, Sun Ch'o (Sun Chuo 孫綽), who is well known as a composer of obituaries and eulogies, composes an obituary for Wang Meng (王蒙) using yu 予 as the first-person pronoun.

(13) 22 輕詆: 孫長樂作王長史評云: ‘余與夫子, 交非勢利, 心猶澄水, 同此玄味。’

'Sun Ch'o composed an obituary for Wang Meng, which went, ' $\mathrm{I}(\mathrm{yu}$ 予) together with the Master - / A friendship not for power or gain. / Our hearts were pure as limpid water, / As we shared this mystic flavor.' (Chapter 26, Contempt and Insults 22)'

$Y u$ 予 is a first-person pronoun used in poems and also in a more archaic form. When Sun (Sun Chuo 孫綽) writes the obituary, he uses the firstperson pronoun $y u$ 予 to show respect to Wang who is of a higher status.

In contrast is an example below, in which $w o$ 我 is used in an obituary instead of $y u$ 予 to show that the person for whom the obituary is written is of a lower status than the writer. 
（14）102文學：桓玄嘗登江陵城南樓云： ‘我今欲為王孝伯作昩。’ 因吟嘯良久, 隨而下筆。一坐之閑, 昩以之成。

'Climbing the Southern Tower of the walls of Chiang-ling, Huan Hsuan said, 'Now I (wo 我) will compose an obituary for Wang Kung.' Whereupon he hummed and whistled for a long while, then immediately set brush to paper. In one sitting the obituary was completed. (Chapter 4, Letters and Scholarship 102)'

With the death of a compatriot, Wang Kung (Wang Gong 王恭), Huan Hsuan (Huan Xuan 桓玄) becomes the new leader of the opposition and has assumed the governorship of Chiang Province. Huan Hsuan (Huan Xuan 桓玄) then says that he will compose an obituary for Wang Kung (Wang Gong 王恭). Since Wang Kung (Wang Gong 王恭) is of a lower status than himself, Huan (Huan Xuan 桓玄) uses the first-person pronoun wo 我 here instead of $y u$ 予.

According to the data in the Analects, $y u$ 予 is used to show respect in relation to matters of higher order such as sickness and death. However, when wo 我 is used in the context of death in the New Tales, such as in the obituary, it is to show that the addressee is of lower status than the writer himself. This shows that the social meaning of wo 我 in the New Tales has absorbed that of $y u$ 予 in the Analects.

\subsection{Absorbing pragmatic functions of $w u$ 吾}

In the Analects, wu 吾 is used when the speaker narrates his own experiences without any emphasis (Wang 2005), usually with a specific addressee in mind. The example below is from the Analects.

（15）孔子曰: ‘見善如不及, 見不善如探湯。吾見其人矣, 吾聞其語矣。隱居以求其志。 行義以達其道。吾聞其語矣, 未見其人也。”

(《论语・季氏 $16.11 》$ )

'Confucius said, 'Seeing what is good I act as if I risked failing to catch with it; seeing what is not good I act as if I were testing hot water.' I ( $w u$ 吾) have met such a man; I ( wu 吾) have heard such a claim. 'I live in retirement in order to attain my purpose and practice what is right in order to realize my way.' I ( $w u$ 吾) have heard such a claim, but I have yet to meet such a man.'

In the example above, Confucius uses $w u$ 吾 to refer to himself when he recounts that he has seen and heard such a noble man.

In the New Tales, instead of wu 吾, wo 我 is also seen to refer to one's own feelings in the example below. 
(16) 40 德行: 殷仲堪既為荊州, 值水儉, 食常五皿盤, 外無餘有。飯粒脫落盤席閒, 輙拾以噉之。雖欲率物, 亦緣其性真素。每語子弟云: ‘勿以我1受任方州, 云 我2豁平昔時意。今吾處之不易。貧者士之常, 焉得登枝而捐其本? 爾曹其存之! ’

'After Yin Chung-k'an had become governor of Ching Province, he encountered a shortage of food due to floods. His meals always consisted of five bowls or dishes, and there was no extra food beyond that. If a grain of rice fell between the dishes and the mat, he would always pick it up and devour it. Although in doing so he wished to set an example for others, he was also following the true simplicity of his nature. He would often say to his sons and younger brothers, 'Don't imagine, because I(wo 我) 1 have accepted office in the present province, that $\underline{\mathrm{I}(w o}$ 我) 2 have given up my usual attitude of earlier days. At present the situation in which we( $w u$ 吾) are living is not easy, but 'poverty is the gentleman's normal state.' Why should he climb out on the branches and lose contact with his roots? You all should preserve this principle!' (Chapter 1, Virtuous Conduct 40)'

In this example, Yin Chung-k'an (Yin Zhongkan 殷仲堪), who has become governor of Ching Province (Jinzhou 荆州), tells his sons and younger brothers that he will not give up the attitude of 'true simplicity', even when he has accepted the office of governor. The first two first-person pronouns used are wo 我, while the third one is $w u$ 吾. The first two first-person pronouns are chosen with the hearers in mind as if to say, '(You don't assume that) I(wo 我)...'. In the third instance, however, he uses $w u$ 吾 to denote a we-inclusive reference describing their collective difficult living conditions. This shows that when wo 我 is used to show one's own situations and feelings in the place of $w u$ 吾, the speaker delivers the utterance with others in mind. Therefore in the New Tales, the wo 我 first-person pronoun has absorbed the function of the $w u$ 吾 pronoun in expressing one's own feelings, albeit speaking in reference to those who are present rather than simply expressing one's own feelings.

This section has shown that in the New Tales, the first-person pronoun wo 我 has absorbed the indexicalities previously used by zhen 朕, yu 予 and $w u$ 吾 in the Analects. This shows that the various first-person pronouns seem to be converging towards the sole pronoun wo 我 in contemporary Chinese. Indeed it is through the pragmatic lens that we are able to solve the mystery of how the many first-person pronominal forms are reduced to one single form eventually. 


\section{Conclusion}

This paper begins with the premise that the different first-person pronominal forms which exist in classical Chinese are driven by different sociopragmatic indexicality and politeness issues. To summarize, the study has examined the pragmatic implications and politeness values of the firstperson pronouns zhen 朕, yu 予, $w u$ 吾, wo 我 and shen 身. In both texts, we have seen that the pronoun zhen 朕 is used by the Emperor with an attitude of respect to Heaven, which has bestowed the position on him. The pronoun $y u$ 予 has been observed as a pronoun used to show respect when discussing matters of death and sickness. The pronoun wo 我 shows emphasis on the speaker when contrasting with others. The pronoun $w u$ 吾 is used for self-reference when talking about personal matters with humility. The pronoun shen 身 treats oneself as an object under discussion. Upon closer examination, we have found that the pronoun wo 我 as it appears in the New Tales has absorbed some sociopragmatic functions of zhen 朕, yu 予, and $w u$ 吾 after a period of several hundred years. This has shown us the beginning of its trajectory of finally being the sole first-person pronoun in contemporary Chinese.

The significance of this study lies in showing us that we cannot take for granted that first-person pronouns are merely self-referencing without pragmatic implications and politeness considerations. As shown in this paper, these seemingly neutral first-person pronouns are indeed loaded with social meanings and politeness that can only be discovered in the particular context of interactions set in its culture. Therefore, this study has shown that we need to put aside assumptions and delve deeper to the particular contexts of each language to discover how pronouns in different languages may carry more meaning than what is seen on the surface.

Till date, the body of politeness literature has been focused on secondperson $\mathrm{T} / \mathrm{V}$ distinctions and first-person forms are largely ignored (e.g., Braun 1988). This study has challenged the implicit assumption that only second-person pronouns are interesting because politeness theories are so anchored in European languages. The emancipatory pragmatic contribution here is that in politeness theories, we often assume conclusions based on the Anglo/European-focus of the field. This study has demonstrated that the exploration of pronouns can take place completely outside the scope of conventional research. It also shows that such insights require pragmatic considerations to uncover rather than relying on traditional grammatical approach. 


\section{Acknowledgements}

I am grateful to the two anonymous reviewers and Professor Dániel Z. Kádár for their helpful comments. I would also like to thank Ms Daoning Zhu for her kind assistance.

\section{References}

\section{Primary sources:}

Lau, Din Cheuk. 2000. The Analects. Hong Kong: The Chinese University Press.

Legge, James. 1991. The Chinese Classics: with a translation, critical and exegetical notes, prolegomena, and copious indexes in five volume, Volume I, Confucius Analects, The Great Learning, The Doctrine of the Mean, third edition. Taipei: SMC Publishing Inc.

Liang, Zhangju. 2002. Chengwei Lu [Record of addressing], Qing dynasty, modern edition used for this paper. Beijing: Zhonghua shuju.

Wilhelm, Richard. 1951. The I Ching or Book of Changes. 2 vols. (English edition, translated by C. F. Baynes). New York: Pantheon Books.

Liu Zhenghao, Qiu Xieyou, Chen Manming, Xu Tanhui and Huang Junlang. 2015. New translation of Shishuo Xinyu 予《世说新语》 新译 [A new account of tales of the world]. Taipei: San Min Book Shop.

Mather, Richard Burroughs. 2002. A new account of tales of the world, second edition. Ann Arbor, MI: Center for Chinese Studies, The University of Michigan.

\section{Secondary materials:}

Agha, Asif. 2007. Language and social relations. Cambridge: Cambridge University Press.

Braun, Friederike. 1988. Terms of address: Problems of patterns and usage in various languages and cultures. Berlin \& New York: Mouton de Gruyter.

Brown, Penelope and Stephen C. Levinson. 1987. Politeness: Some universals in language usage. Cambridge: Cambridge University Press.

Brown, Roger and Albert Gilman. 1960. The pronouns of power and solidarity. In T. A. Sebeok (eds.) Style in language. Cambridge, MA: MIT Press. 253-276.

Elvin, Mark. 1985. Between the earth and heaven: Conceptions of the self in China. In M. Carrithers, S. Collins and S. Lukes (eds.) The category of the person: Anthropology, philosophy, history. Cambridge: Cambridge University Press. 156-189.

Gu, Yueguo. 1990. Politeness phenomena in Modern Chinese. Journal of Pragmatics 14. 237-257.

He, Leshi. 1984. Zuozhuan de renshen 身 daici [Personal pronouns in the Zuozhuan] Gudai hanyu 予 yanjiu lunwenji 2. Beijing: Shekeyuan yuyansuo guhanyu yanjiushi. $108-138$.

He, Ziran and Wei Ren. 2016. Current address behaviour in China. East Asian Pragmatics 1. $163-180$.

Head, Brian F. 1978. Respect degrees in pronominal reference. In J. H. Greenberg (eds.) Universals of human language. Vol. 3: Word structure. Stanford, CA: Stanford University Press. $151-211$. 
Head, Brian F. 1981. Variation and rate of change in the diffusion of new patterns of address. In D. Sankoff and H. Cedergren (eds.) Variation omnibus. Edmonton: Linguistic Research. 489-498.

Helmbrecht, Johannes. 2005. Politeness distinctions in pronouns. In M. Haspelmath et. al. (eds.) The world atlas of language structures. Oxford: Oxford University Press. 186-190.

Hong, Beverly. 1985. Politeness in Chinese: Impersonal pronouns and personal greetings. Anthropological Linguistics 27. 204-213.

Hong, Bo. 1996. Shanggu hanyu 予 diyi rencheng daici 'yu 予', 'wo 我', 'zhen 朕' de fenbie [The difference among Early Chinese first-person pronouns yu 予, wo 我 and zhen 朕]. Yuyan Yanjiu 《语言研究》 1. 80-87.

Huang, Shengzhang. 1963. Gudaiyu 予 de renshen 身 daici yanjiu [Personal pronouns in Archaic Chinese]. Zhongguo Yuwen 6. 443-372.

Huang, Yushun. 2003. Zhongguo chuantong de ‘tazhe' yishi - gudai hanyu 予 rencheng daici de fenxi ['Otherness' in Chinese tradition: An analysis of Archaic Chinese pronouns]. Zhongguo zhexueshi 2. 91-98.

Kádár, Dániel Z. 2007. Terms of (im)politeness: On the communicational properties of traditional Chinese (im)polite terms of address. Budapest: University of Budapest Press.

Kádár, Dániel Z and Michael Haugh. 2013. Understanding politeness. Cambridge: Cambridge University Press.

Kádár, Dániel Z and Yuling Pan. 2012. Chinese 'face' and im/politeness: An introduction. Journal of Politeness Research 8. 1-10.

Lai, Vicky T. and Zygmunt Frajzyngier. 2009. Change of functions of the first-person pronouns. In M. Dufresne, F. Dupuis and E. Vocai (eds.) Historical Linguistics 2007: Selected papers from the 18th International Conference on Historical Linguistics, Montreal, 6-11 August 2007. 223-232.

Lee, Cher Leng. 2012. Self-presentation, face and first-person pronouns in the Analects. Journal of Politeness Research 8. 75-92.

Lee, Cher Leng. 2016. Switching number in pronouns as social indices in Dream of the Red Chamber. East Asian Pragmatics 1. 209-231.

Liu, Yu. 2005. 'Lunyu 予' zhong 'shen 身' 'ji' ‘wo 我' de ziwo 我 daode jiaoyu 予 yiyi [Moral meanings of shen 身, ji, wo 我 in the Analects]. Hengyang shifan xueyuan xuebao 26. $141-144$.

Lo, Yuet Keung. 2001. Lunyu 予 zhong de ziwo 我 guannian [The concept of self in the Analects]. Qinghua Journal 11. 375-393.

Lü Shu-xiang. 1985. Jindai hanyu 予 shidaici [Demonstratives and pronouns in Modern Chinese ]. Shanghai: Xuelin Press.

Mao, LuMing R. 1996. Chinese first-person and social implicature. Journal of Asian Pacific Communication 7. 106-128.

Pan, Yuling and Dániel Z. Kádár. 2011. Politeness in historical and contemporary Chinese. London: Continuum.

Peng, Guoyue. 2000. Kindai Chugokugo no keigo shisutemi [The system of pre-modern Chinese politeness address terms]. Tokyo: Hakuteisha.

Pizziconi Barbara and Richard J. Watts. 2013. Pragmatic and metapragmatic issues in Japanese honorific usage. Berlin \& New York: Mouton de Gruyter. 
Pulleybank, Edwin G. 1995. Outline of Classical Chinese grammar. Vancover: University of British Columbia Press.

Taavitsainen, Irma and Andreas H. Jucker. 2003. Diachronic perspectives on address term systems. Amsterdam \& Philadelphia: John Benjamins.

Tu, Wei-ming. 1994. Embodying the universe: A note on Confucian self-realization. In R. T. Ames, W. Dissanayake and T. P. Kasulis (eds.) Self as person in Asian theory and practice. Albany: State University of New York Press. 177-186.

Wang, Li (ed.). 2000. 王力古漢語字典 [The Wang Li character dictionary of ancient Chinese]. Peking: Zhonghua Shuju.

Wang, Li. 2004. Hanyu 予 shigao [Historical account of Chinese language] Beijing: Zhonghua Shuju.

Wang, Li (ed.). 2000. 王力古漢語字典 [The Wang Li character dictionary of ancient Chinese]. Peking: Zhonghua Shuju.

Wu, Zhongwei. 1999. Lunyu 予 zhong de ziwo 我 guannian tantao [Concepts of self in the Analects]. Xuehai 1. 56-60.

Yuan, Tingdong. 1994. Guren chengwei mantan [Discussions on archaic forms of address]. Beijing: Zhonghua shuju.

Zeng, Lingxiang. 2005. Shijing lunyu 予 zhong diyi rencheng daici 'wo 我' de bijiao [Comparing first-person pronouns in the Book of Odes and Analects] Zaozhuang xueyuan xuebao 22. 86-88.

Zhan, Cheng. 2012. Mediation through personal pronoun shifts in dialogue interpreting of political meetings. Interpreting 4. 192-216.

Zhuang, Zhen. 1984. Shishuo xinyu 予 zhong de rencheng daici [Pronouns in A New Account of the Tales of the World]. Fujian shifan daxue xuebao 4. 77-82. 